\title{
Diskusi Mengenai Isu Strategis Tentang Kelembagaan Pengelolaan Perbatasan Negara dengan Pemerintah Provinsi Maluku
}

\author{
Posma Sariguna Johnson Kennedy ${ }^{1}$, \\ Suzanna Josephine L.Tobing ${ }^{2}$, Rutman L.Toruan ${ }^{3}$, Emma Tampubolon ${ }^{4}$ \\ Universitas Kristen Indonesia, Jakarta, Indonesia ${ }^{1234}$ \\ posmahutasoit2@gmail.com¹, \\ yosephine.tobing@uki.ac.id ${ }^{2}$, rutman.toruan@gmail.com ${ }^{3}$, emma.tampubolon@uki.ac.id ${ }^{4}$
}

\begin{abstract}
ABSTRAK
Diskusi dilakukan dengan beberapa narasumber, yaitu Sekda Provinsi Maluku, Bapeda Provinsi Maluku, Badan Pengelola Perbatasan Provinsi Maluku serta beberapa kelompok masyarakat Maluku di Ambon. Metode yang digunakan adalah diskusi kelompok terarah yang sebagian besar dilaksanakan di Gedung Pusat Pemerintahan Provinsi Maluku. Beberapa permasalahan mendasar dalam pengelolaan perbatasan adalah belum terjalin secara baik mekanisme dan implementasi koordinasi, integrasi, sinkronisasi, dan sinergi program pengelolaan perbatasan nasional baik di tingkat pusat maupun daerah; Ketidakefektifan upaya pengelolaan kelembagaan antar negara dalam mendukung kegiatan lintas batas dan pengelolaan daerah perbatasan dengan negara-negara tetangga; serta terbatasnya sumber daya, infrastruktur pendukung, dan kurangnya sumber daya manusia untuk lembaga pengelola perbatasan. Perlu penguatan kelembagaan, pelatihan sumber daya manusia dan kecukupan penyediaan dana yang dibutuhkan sesuai dengan prioritasnya.
\end{abstract}

Kata kunci: Kelembagaan, Pengelolaan Perbatasan, Perbatasan Negara, Badan Pengelola Perbatasan Negara, Badan Pengelola Perbatasan Daerah.

\begin{abstract}
The purpose of this paper is to increase understanding of a problem, with the topic of understanding strategic issues about institutions in managing national borders. The discussion was conducted with several speakers, namely Secretary of Maluku Province, Bapeda Maluku Province, Border Management Agency of Maluku Province, and several Maluku community groups in Ambon. The method used is focus group discussions which are mostly carried out in the Central Government Building of Maluku Province. Some of the fundamental problems in border management are that the mechanism and implementation of coordination, integration, synchronization, and synergy of national border management programs are not well established at the central and regional levels; The ineffectiveness of efforts to manage inter-state institutions in supporting cross-border activities and management of border areas with neighboring countries; and limited resources, supporting infrastructure, and lack of human resources for border management institutions. There needs to be institutional strengthening, training in human resources, and the adequacy of the provision of funds required by its priorities.
\end{abstract}

Keywords: Institutional, Border Management, StateBorder 


\section{PENDAHULUAN}

Visi Negara Kesatuan Republik Indonesia (NKRI) perlu diwujudkan sesuai dengan harapan pemerintah dan semua pemangku kepentingan. Penentuan berbagai kebijakan harus direncanakan dengan baik melalui implementasi yang akurat dan cepat. Program-program kerja harus menyentuh semua orang untuk peningkatan kesejahteraan masyarakat. Selalu ada perbedaan dalam kondisi umum saat ini dengan ketika merencanakan.

Negara Kesatuan Republik Indonesia memiliki 10 provinsi yang berbatasan dengan Negara tetangga, yaitu Provinsi Kepulauan Riau, Kalimantan Timur, Kalimantan Barat, NTT, Papua, Sulawesi Utara, NAD, Riau, Maluku, Maluku Utara. Namun demikian hanya 6 diantaranya yang memiliki Badan Pengelola Perbatasan pada tingkat provinsi. Keenam provinsi tersebut adalah Provinsi Kepulauan Riau, Kalimantan Timur, Kalimantan Barat, NTT, Papua, dan Sulawesi Utara.

Wilayah Perbatasan Negara di Provinsi Maluku mencakup wilayah perbatasan di laut. Wilayah perbatasan ini adalah perbatasan laut yang terdiri dari: Gugus Kepulauan Aru, Gugus Kepulauan Kei, Gugus Kepulauan Tanimbar, Gugus Kepulauan Tanimbar, Gugus Kepulauan Babar, dan Gugus Kepulauan Terselatan.

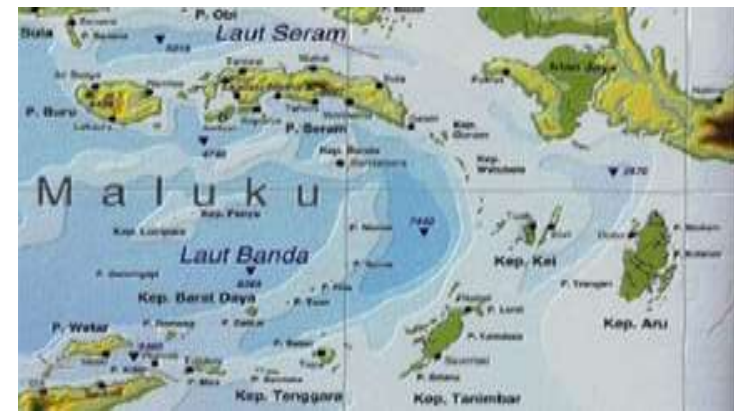

Gambar 1. Peta Kepulauan Maluku Sumber:https://www.tribun-maluku.com /2017/10/praja-ipdn-ditempatkan-di-wilayahperbatasan-maluku/

Mengelola perbatasan nasional dan wilayah perbatasan bukanlah tugas yang mudah. Namun, tugas mulia ini harus dijalankan dengan serius sebagai tanggung jawab menjalankan amanat konstitusi. Kelembagaan adalah salah satu kunci untuk mengelola daerah perbatasan. Tidak semua daerah memiliki lembaga khusus yang mengelola wilayah perbatasan. Beberapa daerah yang sudah memiliki badan pengelola perbatasan masih menghadapi masalah strategis dalam mengelola wilayah perbatasan. Kurangnya kejelasan otoritas, kurangnya sumber daya manusia dan aset manajemen, serta beberapa isu strategis lainnya yang terkait dengan lembaga manajemen perbatasan nasional masih menjadi salah satu masalah fokus yang masih belum dapat diatasi di wilayah perbatasan Negara Kesatuan Republik. dari Indonesia.

Manajemen perbatasan sangat strategis dan penting, mengingat bahwa hal itu terkait langsung dengan upaya 
menegakkan kedaulatan nasional, menegakkan pertahanan dan keamanan nasional, memanfaatkan sumber daya dan pembangunan yang adil, serta tanggung jawab bersama dalam mengembangkan daya saing masyarakat untuk menyeimbangkan kegiatan sosial ekonomi. negara tetangga. (Istijono, 2012) Isolasi daerah perbatasan nasional adalah masalah utama perbatasan, karena keterbatasan infrastruktur dasar daerah, yaitu transportasi, energi (listrik dan bahan bakar), komunikasi dan informasi, menyebabkan pertumbuhan ekonomi yang lambat, dan kurangnya layanan sosial dasar, terutama pendidikan dan kesehatan. (Poetro, 2015)

Pengelolaan batas negara tidak dapat dipisahkan dari sistem perencanaan pembangunan nasional. Dalam konteks pembangunan di Indonesia, perencanaan pembangunan diatur dalam UU 25/2004 tentang Sistem Perencanaan Pembangunan Nasional. Dalam hal ini, pengelolaan batas negara merupakan bagian dari pembangunan nasional sehingga memiliki posisi tertentu pada dokumen perencanaan pembangunan, sehingga rencana yang telah disiapkan dapat diimplementasikan sebagai mekanisme pembangunan nasional. (BNPP RI, 2015, Rinduk, 2015-2019)

Pengelolaan wilayah perbatasan dilakukan oleh Badan Pengelola Perbatasan Nasional (BNPP) yang mengoordinasikan lembaga terkait seperti departemen di pemerintahan dan pemerintah daerah. Mekanisme koordinasi lembaga BNPP pusat-daerah dilaksanakan berdasarkan Peraturan Presiden Nomor 12 Tahun 2010. Kepala BNPP (Menteri Dalam Negeri) dalam melaksanakan tugasnya dapat mengundang dan termasuk menteri, pemimpin lembaga pemerintah nonkementerian, dan pejabat lain dari lembaga pemerintah, pemerintah daerah dan nonpemerintah sesuai kebutuhan. (BNPP, 2015)

Dalam menjalankan tugas dan fungsinya, BNPP berkoordinasi dengan badan pengelola perbatasan di tingkat daerah. Hubungan koordinasi antara BNPP dan badan pengelola perbatasan daerah mencakup bimbingan, fasilitasi, dan pengawasan. Dalam menjalankan tugas dan fungsinya, badan pengelola perbatasan di daerah tersebut dikoordinasikan oleh Gubernur dalam posisinya sebagai wakil dari Pemerintah dan anggota BNPP. Prosedur untuk hubungan kerja BNPP dengan badan manajemen perbatasan di daerah diatur oleh Kepala BNPP. (BNPP, 2015)

Di daerah perbatasan yang sedang berkembang, Pusat Kegiatan Strategis Nasional (PKSN) menjadi strategi yang sangat penting. PKSN adalah kawasan perkotaan yang telah dibentuk untuk mendorong pengembangan wilayah perbatasan Negara. Pengembangan PKSN dimaksudkan untuk menyediakan layanan yang dibutuhkan untuk mengembangkan 
kegiatan masyarakat di daerah perbatasan, termasuk layanan untuk kegiatan lintas batas antar negara. Dalam rencana struktur dan pola spasial wilayah nasional, di Provinsi Maluku ada 3 PKSN, yaitu Dobo di Kabupaten Kepulauan Aru, Ilwaki di Maluku Barat Daya dan Kabupaten Saumlaki di Kabupaten Maluku Tenggara Barat. Tiga wilayah kota tersebut termasuk dalam percepatan pengembangan kota-kota utama baru di wilayah perbatasan.

Lokasi Prioritas (Lokpri) adalah kecamatan di wilayah perbatasan darat dan laut di Wilayah Konsentrasi Pengembangan (WKP). Penyusunan Rencana Induk Lokasi Prioritas (Lokpri) harus mempertimbangkan berbagai kebijakan di tingkat nasional, provinsi dan kabupaten, dan berdasarkan pada proses penyaringan aspirasi masyarakat di tingkat kecamatan, kabupaten, provinsi dan nasional. Rencana Lokpri diharapkan dapat memberikan arahan bagi pengembangan kawasan perbatasan secara komprehensif dan menjadi input bagi proses perumusan kebijakan pengembangan kawasan perbatasan di tingkat nasional, provinsi, dan kabupaten sehingga terbentuk kebijakan pengelolaan kawasan perbatasan yang terintegrasi dengan baik (BNPP, 2011).

Kecamatan-kecamatan di Provinsi Maluku milik kelompok Lokpri Laut, di mana kecamatan tersebut berbatasan langsung dengan negara-negara tetangga di wilayah laut dan berfungsi sebagai PKSN. Ruang lingkup penyusunan Rencana Induk untuk
Pengelolaan Wilayah Negara dan Perbatasan berdasarkan Lokasi Prioritas untuk 2015-2019 di Provinsi Maluku adalah di 8 Lokasi Prioritas yang tersebar di 4 Kabupaten. (BNPP, 2015)

Dalam paper ini, penulis ingin memahami lebih dalam mengenai pengelolaan perbatasan negara, khususnya di wilayah Provinsi Maluku. Diskusi dengan berbagai nara sumber dan Buku Rencana Induk Pengelolaan Perbatasan Nasional 2015-2019 yang dikeluarkan oleh BNPP menjadi acuan penulis sebagai bahan penulisan paper ini.

Pengelolaan perbatasan dilasanakan oleh badan khusus yang bertanggung jawab sesuai dengan mandat UndangUndang No.43/2008 tentang Wilayah Negara. Berdasarkan mandat UndangUndang (UU) tersebut, Peraturan Presiden (Perpres) Nomor 12 tahun 2010 tentang Badan Pengelola Perbatasan Nasional (BNPP) ditetapkan. Pembentukan BNPP dimaksudkan untuk membuat manajemen perbatasan lebih fokus, sinkron, terkoordinasi, dan pada pintu manajemen yang sama. (BNPP, 2015)

Dalam rangka mengelola perbatasan negara dan pengembangan wilayah perbatasan, BNPP merumuskan dokumen manajemen yang terdiri dari Desain Besar, Rencana Induk, dan Rencana Aksi untuk Pengelolaan Perbatasan Negara sebagai referensi bersama bagi para pemangku kepentingan dalam pengembangan wilayah perbatasan, dan sebagai upaya untuk 
mengarusutamakan batas pembangunan daerah ke dalam kebijakan pemerintah. Ketiga dokumen tersebut saling melengkapi dan menguraikan dokumen perencanaan seperti RPJPN, RPJMN, dan Rencana Kerja Pemerintah (RKP) dan Rencana Kerja dan Anggaran (RKA). (BNPP, 2015)

Dalam kerangka pembangunan di Indonesia, dokumen rencana pembangunan berfungsi untuk memberikan arahan bagi terciptanya integrasi, sinkronisasi, dan sinergi dalam pembangunan antar daerah, antar ruang, antar fungsi, antar sektor, dan antara Pemerintah Pusat dan Daerah. Dokumen rencana pembangunan ini menyediakan payung konseptual untuk pengembangan umum di suatu wilayah, baik untuk pembangunan fisik maupun nonfisik, baik spasial dan non-spasial. Arahan pembangunan yang dirumuskan pada dasarnya adalah penjabaran dari agenda pembangunan yang ditetapkan oleh Presiden (di tingkat nasional)/ Kepala Daerah (di tingkat provinsi/kabupaten/kota). (BNPP, 2015)

Dalam rangka mengelola batas-batas negara, Rencana Induk Pengelolaan Perbatasan Negara berkaitan dengan sistem perencanaan pembangunan nasional, sehingga konten dalam rencana induk dapat diimplementasikan secara konkret dalam perencanaan pembangunan. Sehubungan dengan rencana pembangunan baik nasional maupun regional, perlu untuk menyinkronkan rencana pembangunan dan rencana induk untuk mengelola perbatasan nasional. Ini dilakukan agar rencana yang disusun bisa sinkron dan saling melengkapi. (BNPP, 2015)

Pengelola Perbatasan di Tingkat Pusat dan Daerah (BNPP, 2015). BNPP merupakan Badan Pengelola Perbatasan di tingkat pusat, seperti halnya Badan Nasional lain yang dibentuk oleh Peraturan Presiden, berkedudukan di bawah dan bertanggung jawab kepada Presiden.

Sesuai UU N0.43/2008 Pasal 15 dan Perpres No.12/2010 Pasal 3, BNPP bertugas menetapkan kebijakan program pembangunan perbatasan, menetapkan rencana kebutuhan anggaran, mengkoordinasikan pelaksanaan, serta melaksanakan evaluasi dan pengawasan terhadap pengelolaan batas wilayah negara dan kawasan perbatasan. Berdasarkan landasan landasan hukum tersebut, dalam pengelolaan perbatasan BNPP pun berperan sebagai regulator, koordinator, akselerator, dan dinamisator. (Istijono 2012) BNPP dikepalai oleh seorang Menteri Dalam Negeri dan terdiri dari 15 anggota, baik Menteri, Kepala Lembaga Pemerintah, Kepala Lembaga Pemerintah nonKementerian, maupun Gubernur Provinsi terkait. Selaku Kepala BNPP, Menteri Dalam Negeri memimpin dan mengendalikan pelaksanaan tugas dan fungsi BNPP. Dalam kesehariannya, tugas BNPP yang dilakukan oleh Menteri Dalam Negeri ini dilakukan oleh Sekretaris BNPP melalui Sekretariat BNPP. Selain 
membantu tugas Kepala BNPP, Sekretariat BNPP juga memberikan dukungan teknis, koordinatif dan administratif. (Peraturan Menteri Dalam Negeri No.31/2010)

Dalam penyelenggaraan tugas dan fungsinya, BNPP melakukan koordinasi dengan badan pengelola perbatasan di tingkat daerah; Hubungan koordinasi antara BNPP dan badan pengelola perbatasan daerah meliputi pembinaan, fasilitasi dan pengawasan; Dalam penyelenggaraan tugas dan fungsinya badan pengelola perbatasan di daerah dikoordinasi oleh Gubernur dalam kedudukannya sebagai wakil Pemerintah dan anggota BNPP; Tata cara hubungan kerja BNPP dengan badan pengelola perbatasan di daerah diatur oleh Kepala BNPP.

Untuk kewenangan pengelolaan daerah, Peraturan Menteri Dalam Negeri No.02/2011 menyebutkan bahwa Pembentukan Badan Pengelola Perbatasan (BPP) Provinsi ditetapkan dengan Peraturan Daerah. Keberadaan Badan Pengelola Perbatasan di provinsi bervariasi, terdapat badan yang sudah dibentuk sebelum arahan mengenai pembentukan BPP di daerah ditetapkan oleh Peraturan Menteri Dalam Negeri. Dalam pelaksanannya, pengelola perbatasan masih ada yang bergabung dengan instansi lain karena mengalami kesulitan dalam memprioritaskan pembangunan wilayah perbatasan. Beberapa BPP di tingkat provinsi yang memiliki dasar hukum pembentukan berupa Peraturan Daerah, namun untuk sementara pada provinsi Maluku masih bergabung di dalam Dinas di tingkat provinsi yang mengacu kepada Peraturan Daerah Instansi lain yang menaunginya.

Mekanisme koordinasi antara badan pengelola perbatasan di daerah dan badan pengelola perbatasan yang berada di pusat diatur dalam Peraturan Menteri Dalam Negeri 02/2011. Kewenangan BPP di tingkat provinsi juga diatur dalam peraturan tersebut. Otoritas ini meliputi:

- Melaksanakan kebijakan pemerintah dan menetapkan kebijakan lain dalam rangka otonomi daerah dan tugas pembantuan;

- Mengkoordinasikan pembangunan di daerah perbatasan;

- Untuk mengembangkan daerah perbatasan antar pemerintah dan/atau antara pemerintah daerah dan pihak ketiga;

- Mengawasi pelaksanaan pengembangan wilayah perbatasan yang dilakukan oleh pemerintah kabupaten/kota.

\section{Berdasarkan Peraturan Presiden} No.12/2010 dinyatakan bahwa Badan Pengelola Perbatasan Daerah memiliki fungsi koordinasi dengan BNPP dengan hubungan kerja yang diatur oleh kepala BNPP. Dalam peraturan BNPP No. 2 tahun 2011, BNPP diwakili oleh Biro Perencanaan, melaksanakan fungsi mempersiapkan dan melaksanakan kerja 
sama lintas sektoral dan kerja sama antara pusat dan daerah. Berikut ini adalah bagan kolaborasi BNPP dan BPP provinsi.

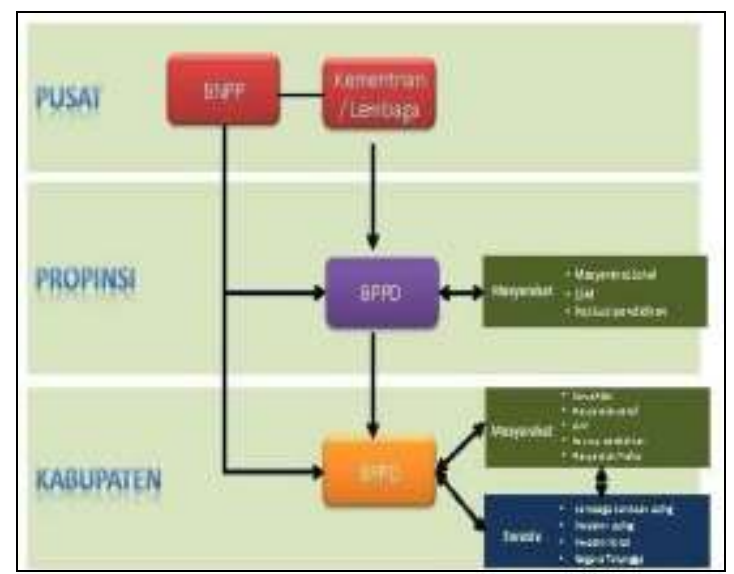

Gambar 2. Kerjasama Pengelolaan Perbatasan, BNPP dan BPPD

Sumber: BNPP, 2015

METODE

Paper ini merupakan luaran dari kegiatan pengabdian kepada masyarakat yang bertujuan untuk meningkatkan pemahaman tentang suatu masalah. Topik yang didalami adalah pemahaman mengenai isu-isu strategis tentang kelembagaan dalam pengelolaan perbatasan negara. Kegiatan ini dilakukan dengan metode diskusi, dengan nara sumber pemerintah Provinsi Maluku, di Ambon. Karena kesulitan menyatukan anggota diskusi, penulis dan tim melakukannya secara terpisah sesuai dengan kesempatan yang mereka miliki. Peserta Diskusi dilakukan dengan beberapa narasumber, yaitu Sekda Provinsi Maluku, Bapeda Provinsi Maluku, BPPP Maluku serta beberapa kelompok masyarakat Maluku di Ambon. Karena seluruh peserta
Dari gubernur provinsi terkait, tugas mengelola perbatasan di daerah diturunkan ke badan pengelola perbatasan regional. diskusi berlatar belakang Pendidikan tinggi, maka metode yang paling tepat adalah diskusi kelompok terarah atau focus group discussion (FGD). Lokasi dan Waktu. Kegiatan itu dilakukan di Gedung Pusat Pemerintahan Provinsi Maluku, Jl. Dr. Latumeten Ambon, pada 8-12 November 2018.

\section{PEMBAHASAN}

Pengelolaan perbatasan dilakukan dengan melalui tiga pendekatan, yaitu pendekatan kesejahteraan (prosperity approach), pendekatan lingkungan (environment approach) dan pendekatan keamanan (security approach). Semuan pendekatan itu bukanlah hal yang mudah untuk dilaksanakan (Kennedy, 2018). Terdapat berbagai isu strategis terhadap kelembagaan pengelolaan perbatasan negara, diantaranya adalah:

Tidak optimalnya mekanisme dan implementasi koordinasi, integrasi, sinkronisasi dan sinergi program pengelolaan perbatasan nasional baik di pusat maupun di tingkat regional; Ketidakefektifan upaya pengelolaan kelembagaan antar negara dalam mendukung kegiatan lintas batas dan integrasi pengelolaan daerah perbatasan dengan negara tetangga; Terbatasnya sumber daya, infrastruktur pendukung, dan 


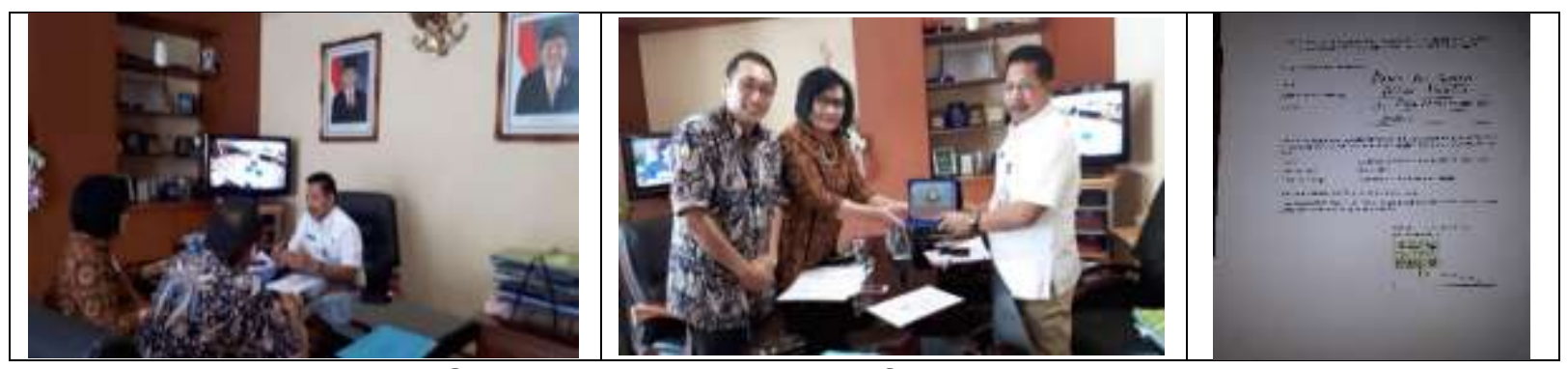

Gambar 3. Diskusi Bersama Sekda Provinsi Maluku

Masalah mendasar pertama adalah mekanisme dan implementasi koordinasi, integrasi, sinkronisasi, dan sinergi program manajemen perbatasan nasional baik di tingkat pusat maupun daerah. Badan Pengelola Perbatasan (BPP) Provinsi dan BPP Kabupaten harus bisa melakukan koordinasi dengan Satuan Kerja Perangkat Daerah (SKPD) dan lembaga hukum terkait dalam melakukan pengawasan. BPP provinsi dan kabupaten kurang melibatkan masyarakat untuk membantu tugas BPP provinsi dan kabupaten dalam melaksanakan tugas mengawasi penggunaan sumber daya alam. Dapat disimpulkan bahwa masalah yang terkait dengan aspek regulasi dalam masalah pelanggaran penggunaan sumber daya alam adalah kurangnya penguatan pengawasan dan koordinasi, dan tidak adanya otoritas dari badan pengelola perbatasan untuk memberikan laporan tentang kinerja SKPD terkait dengan pengelola sumber daya alam di daerah perbatasan.

Lembaga yang tergabung dalam SKPD tidak bebas untuk mengumpulkan dana, termasuk juga badan pengelola perbatasan karena masih berafiliasi dengan lembaga lain, sehingga mereka kurang mendapatkan anggaran. Selain itu, kontribusi pemerintah pusat dan provinsi terhadap penyediaan dana untuk program untuk daerah perbatasan masih sangat kurang. Kegiatan pengelolaan perbatasan di tingkat provinsi dan kabupaten tidak hanya melakukan koordinasi, tetapi juga melakukan kegiatan kerjasama-kerjasama spasial, pemberdayaan ekonomi masyarakat, operasi imigrasi, aksesibilitas transportasi, pelaksanaan pemantauan evaluasi. Berbagai kegiatan terhambat karena keterbatasan dana.

Tipologi ini terkait dengan tipologi lain, yaitu tipologi kemampuan sumber daya manusia (SDM). SDM yang ada tidak mampu merumuskan kebijakan pembangunan yang ada, sehingga dalam desain anggaran hanya terdapat belanja pegawai dan aset. Terbatas kegiatan untuk program pembangunan kaitannya adalah kurangnya otoritas BPP provinsi dan kabupaten dalam mengawasi proposal kebijakan program dan sinkronisasi 
kebijakan program pembangunan antara tingkat pusat, provinsi, dan daerah. Akibatnya, anggaran yang diberikan di daerah perbatasan seringkali tidak tepat sasaran, karena pembuat keputusan anggaran tidak benar-benar memahami kebutuhan prioritas daerah perbatasan.
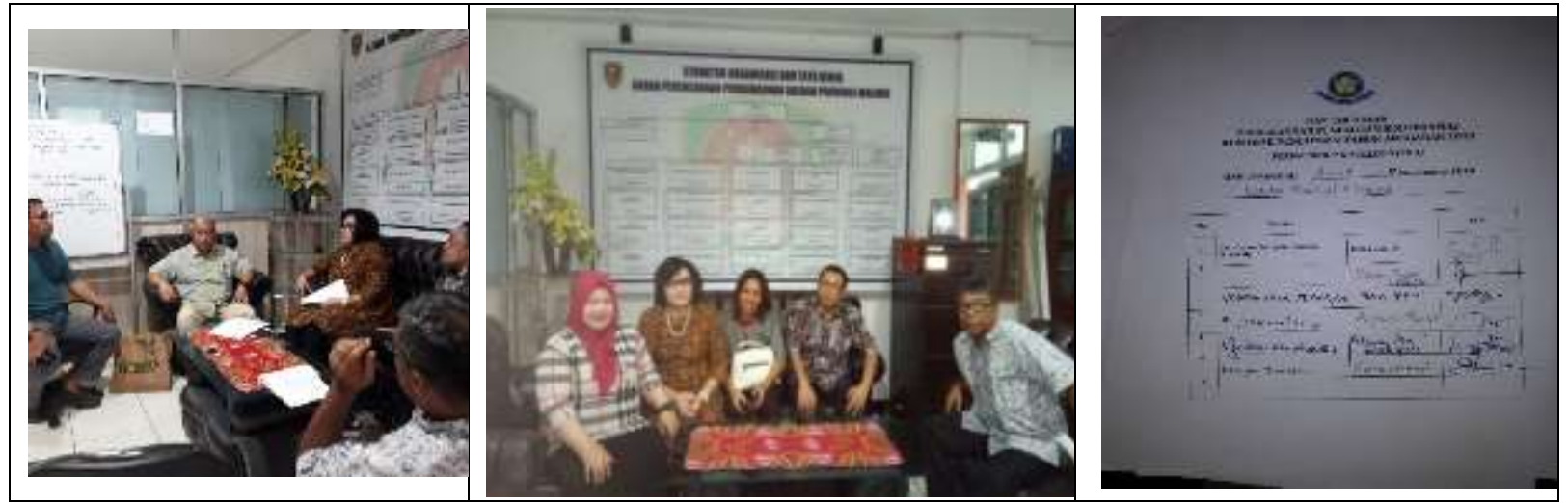

Gambar 4. Diskusi Bersama Bapeda Provinsi Maluku

Masalah mendasar kedua adalah ketidakefektifan upaya manajemen kelembagaan antar negara dalam mendukung kegiatan lintas batas dan integrasi pengelolaan daerah perbatasan dengan negara-negara tetangga. Badan pengelola perbatasan saat ini hanya berfokus pada pengembangan fisik di wilayah perbatasan darat dan laut. Namun seringkali perkembangannya tidak efektif, terutama untuk mengakomodasi aktivitas lintas batas dengan negara-negara tetangga yang sebenarnya merupakan darah kehidupan ekonomi di wilayah perbatasan. Kelemahan dari fokus lembaga pengelola perbatasan dalam hal ini tidak dapat menghasilkan sinergi antara pengembangan wilayah dan satu sama lain, sehingga terjadi ketimpangan ekonomi, infrastruktur dan sosial di wilayah perbatasan. Fokus pada kegiatan lintas batassebenarnya dapat dicapai dengan membentuk lembaga pengelolaan bersama antara dua negara di wilayah perbatasan baik darat maupun laut. Di mana ada komitmen antara kedua negara untuk mensinergikan kebijakan pembangunan bersama sesuai dengan kebijakan negara masing-masing, dengan tujuan yang sama, yaitu mengembangkan daerah perbatasan. Kemudian lembaga gabungan ini merumuskan kebijakan bersama dalam bentuk kerja sama antara dua negara di bidang pembangunan, kegiatan ekonomi, sosial dan budaya dalam rangka meningkatkan kesejahteraan wilayah perbatasan. (BNPP, 2015)

Beberapa lembaga kolaboratif sebenarnya sudah ada, tetapi secara umum mereka hanya terbatas pada perjanjian tentang batas negara dan kerja sama ekonomi sementara. Perlu ada lembaga 
perbatasan bersama yang secara khusus terletak di setiap wilayah perbatasan, seperti yang telah dilakukan di negaranegara Eropa, dimana perwakilan pemerintah pusat dan pemerintah daerah di wilayah perbatasan duduk bersama untuk membentuk kebijakan kerjasama bersama. Dengan adanya badan pengelola perbatasan bersama, diharapkan kolaborasi tersebut dapat mengakomodasi semua kebutuhan wilayah perbatasan sesuai dengan kebutuhan wilayah perbatasan yang memiliki potensi dan karakteristik berbeda. Dan tujuan utama dari lembaga perbatasan bersama adalah untuk meningkatkan sinergi antar negara di wilayah perbatasan untuk meningkatkan kesejahteraan masyarakat perbatasan. (BNPP, 2015) Masalah mendasar ketiga adalah sumber daya yang terbatas, infrastruktur pendukung, dan kurangnya sumber daya manusia untuk lembaga pengelola perbatasan. Terbatasnya sumber daya adalah seperti sumber daya keuangan, kejelasan tugas dan fungsi, dan lain-lain. Yang masih belum secara jelas diterapkan dan diatur, terutama dalam posisi otoritas daerah. Jika melihat alur masalahnya, terlihat bahwa di tingkat pusat, masalah yang menyebabkan keterbatasan aset manajemen adalah masalah koordinasi vertikal dengan BPPD dalam meminta bantuan untuk penyediaan aset, sedangkan di daerah masalahnya adalah koordinasi horisontal dengan institusi lain yang terkait dengan perbatasan, serta masalah pola pikir pengelolaan kawasan perbatasan dalam penyediaan aset. Selain sumber masalah, ada faktor-faktor berpengaruh lainnya, yaitu sumber daya keuangan yang tidak mencukupi untuk menyediakan semua aset, dan prosedur yang tidak jelas untuk mengusulkan rencana anggaran untuk pengembangan wilayah perbatasan dari daerah ke pusat. Peraturan Menteri Dalam Negeri No. 02/2011 hanya mengatur prinsip-prinsip yang harus dilakukan oleh badan manajemen, yaitu prinsip koordinasi, integrasi dan sinkronisasi dalam menjalankan tugas di Kabupaten dan Provinsi. Namun, tidak ada mekanisme standardisasi dalam koordinasi sehingga perlu diatur lebih lanjut dalam peraturan yang lebih teknis. (BNPP, 2015)

Selain itu, masalah lainnya adalah yang berkaitan dengan keterbatasan kapasitas sumber daya manusia di berbagai daerah perbatasan. Banyak sumber daya manusia dari daerah perbatasan yang lebih akrab dengan daerah mereka tidak direkrut atau dijadikan aktor penting dalam mengelola daerah perbatasan. Masalah selanjutnya adalah potensi yang belum optimal untuk melibatkan kelompok masyarakat adat (yang dianggap memahami wilayah secara nyata) dalam mengelola perbatasan (diplomasi penetapan batas). 

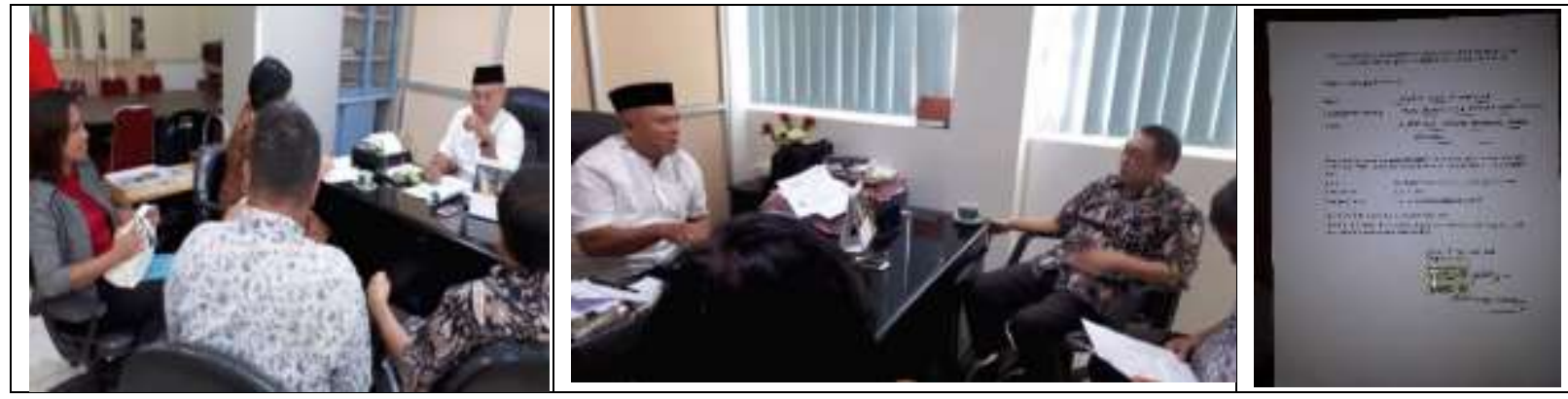

Gambar 5. Diskusi Bersama BPP Wilayah Maluku

Selain sejumlah masalah terkait, ada juga beberapa faktor lain sebagai masalah kemampuan sumber daya manusia yang terbatas. Kapabilitas kemampuan SDM terbatas adalah karena kurangnya pelatihan, yang membutuhkan dana operasional. Kapasitas kemampuan SDM sangat terkait dengan pelatihan dan pendidikan yang diberikan kepada SDM. Kegiatan pelatihan dan pendidikan ini juga membutuhkan dukungan keuangan untuk mencapai tujuan meningkatkan kompetensi SDM yang dibutuhkan. Kemampuan sumber daya manusia terbatas karena pemerintah daerah tidak membiayai masyarakat lokal untuk mengambil bagian dalam pendidikan, dapat disebabkan oleh kemampuan pemerintah daerah untuk membiayai sumber daya manusia melalui pendidikan dan pelatihan. Apresiasi staf pengajar juga masih kurang, dan terbatasnya akses SDM untuk berpartisipasi dalam pendidikan dan pelatihan untuk meningkatkan kompetensi mereka. Ketidakefisienan dalam kegiatan pelatihan karena dilaksanakan di luar daerah, serta waktu pembelajaran yang tidak efisien. Upaya untuk meningkatkan kualitas sumber daya manusia belum didorong sepenuhnya. Salah satu peningkatan kualitas sumber daya manusia juga dipengaruhi oleh seberapa banyak upaya yang telah dilakukan pemerintah terkait peningkatan kualitas sumber daya manusia.

Masih ada provinsi/kabupaten yang belum memiliki badan pengelola perbatasan yang berdiri sendiri, yang merupakan masalah yang menyebabkan terbatasnya kemampuan sumber daya manusia. Sehingga BPP tidak memiliki wewenang untuk mengatur kebijakan dalam merekrut sumber daya manusia yang mampu mengelola perbatasan. Selanjutnya, peraturan yang mengatur kualifikasi SDM dalam Peraturan Menteri Dalam Negeri No. 02/2011 hanya mengatur kualifikasi kepala badan pengelola. Oleh karena itu, diperlukan lebih banyak peraturan teknis yang mengatur kualifikasi SDM semua staf lembaga pengelola perbatasan untuk 
menyaring kualitas sumber daya manusia di dalam badan pengelola perbatasan. Masalah terbatasnya jumlah sumber daya manusia di tingkat pusat, provinsi dan kabupaten menjadi problem yang serius.

Penyediaan SDM terhalang oleh kurangnya insentif untuk bekerja di perbatasan. Kurangnya insentif bagi pengelola perbatasan akan mengurangi tingkat kesejahteraan pelaksana. Kebijakan pusat harus mempertimbangkan faktor ini untuk meningkatkan minat calon SDM sebagai pengelola daerah perbatasan. Salah satu kekurangan sumber daya manusia dapat disebabkan oleh kurangnya penghargaan atas keberadaan profesi SDM pengelola perbatasan. Selain itu, belum optimalnya keterlibatan warga setempat sebagai pekerja di perbatasan. Keterlibatan sumber daya manusia lokal pada dasarnya membantu mengatasi masalah terbatasnya jumlah sumber daya manusia.

Tidak ada peraturan yang mengatur jumlah ideal anggota/staf BPP di suatu daerah. Regulasi yang tercantum dalam Peraturan Menteri Dalam Negeri No. 02/2011 hanya mengatur struktur organisasi, tetapi tidak ada regulasi teknis mengenai jumlah ideal anggota/staf badan pengelola perbatasan. Luasnya area yang dikelola oleh BPP adalah faktor penting yang menentukan kebutuhan. Keberadaan badan pengelola perbatasan masih diperlukan untuk dalam mengoordinasikan pengelolaan wilayah perbatasan, sehingga diperlukan peraturan mengenai jumlah anggota/staf ideal yang disesuaikan dengan wilayah perbatasan yang luas.

Masalah lain adalah kurangnya standar layanan di daerah perbatasan, khususnya untuk standar layanan yang baik di bidang kesehatan, pendidikan, lingkungan, penyediaan infrastruktur dan layanan lainnya. Standar pelayanan yang telah dibuat oleh pemerintah kadangkadang tidak tepat untuk diterapkan di daerah perbatasan, karena daerah perbatasan sangat unik dengan posisinya yang strategis dan perannya sebagai pintu masuk ke Indonesia. Aktor di wilayah perbatasan yang memiliki peran dalam masalah ini adalah pemerintah pusat dan pemerintah daerah. Pemerintah pusat memiliki akses khusus ke lembagalembaga yang memiliki wewenang dalam membuat standar layanan, sedangkan pengelola daerah memiliki akses ke SKPD yang terkait langsung dengan layanan pemerintah di wilayah perbatasan. Masalah yang terjadi adalah belum kuatnya pengelola perbatasan koordinasi dengan SKPD dalam mengembangkan standar layanan. (BNPP, 2015)

Keterbatasan

kemampuan pengelolaan perbatasan dapat disebabkan lembaga pengelola masih bergabung dengan lembaga lain, sehingga badan pengelola kabupaten/provinsi tidak memiliki kebebasan untuk mengembangkan berbagai program. Integrasi badan pengelola dengan 
lembaga lain membuat berbagai program kegiatan pembangunan perbatasan harus pembangunan yang lain. Realisasi prioritas program kegiatan pembangunan perbatasan akan terbantu jika ada dorongan dari pemerintah pusat dan provinsi yang dicanangkan dalam rencana strategis dan rencana aksi untuk kementerian/departemen terkait.

Pengelola perbatasan kabupaten yang masih berafiliasi dengan SKPD lainnya tidak dapat bebas, berkenaan dengan persiapan program kegiatan yang berkaitan dengan tugas dan fungsi

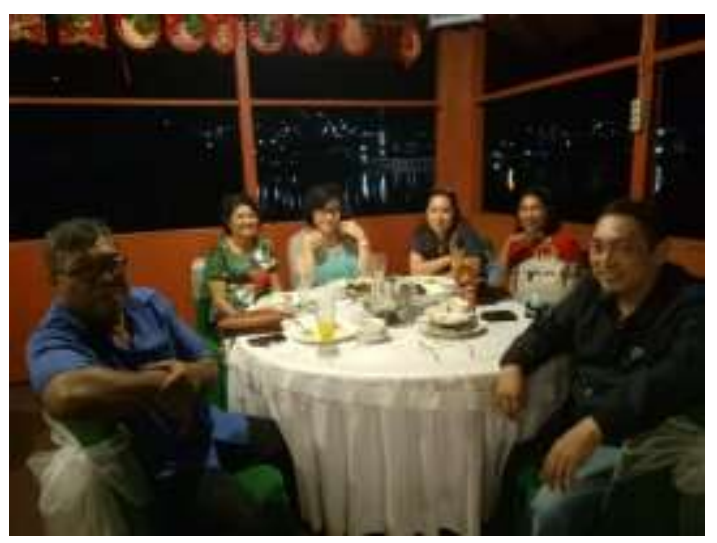

Gambar 6. Diskusi Bersama Kelompok Masyarakat Maluku

\section{KESIMPULAN}

Koordinasi kelembagaan dari Badan Nasional Pengelola Perbatasan (BNPP) antara pusat-daerah didasarkan pada Peraturan Presiden No.12/2010. Hubungan koordinasi antara BNPP dan badan pengelola perbatasan daerah mencakup bimbingan, fasilitasi, dan pengawasan. Dalam menjalankan tugas dan fungsinya, badan pengelola perbatasan di daerah, dikoordinasikan dinegosiasikan dengan prioritas

pengeloaan administrasi kabupaten. Lembaga pengelola perbatasan cenderung menyesuaikan diri dengan SKPD lainnya. Keterbatasan program kegiatan juga terkait dengan ketidakmampuan lembaga pengelola untuk mendorong prioritas program pengembangan wilayah perbatasan oleh SKPD. Program perbatasan sepertinya masih belum menjadi prioritas untuk rencana aksi $\begin{array}{lll}\text { SKPD. } & \text { (BNPP, }\end{array}$

oleh Gubernur sebagai wakil dari pemerintah dan anggota BNPP. Hubungan kerja BNPP dengan badan pengelola perbatasan di daerah diatur oleh Kepala BNPP. Kewenangan BPP di tingkat provinsi diatur dalam Peraturan Menteri Dalam Negeri 02/2011, meliputi: Melaksanakan kebijakan pemerintah dan menetapkan kebijakan lain dalam rangka otonomi daerah dan tugas pembantuan bersama; Mengkoordinasikan pembangunan di wilayah perbatasan; Untuk mengembangkan daerah perbatasan antar pemerintah dan/atau antara pemerintah daerah dan pihak ketiga; dan Mengawasi pelaksanaan pengembangan wilayah perbatasan yang dilakukan oleh pemerintah kabupaten/kota. Dari hasil diskusi, masih diperlukan penguatan kelembagaan, pelatihan sumber daya manusia dan penyediaan 
dana yang dibutuhkan, sesuai dengan prioritas penanganan perbatasan Negara.

\section{UCAPAN TERIMA KASIH}

Kami berterima kasih kepada Kemenristek Dikti, DRPM atas Hibah Simlibtamas, Lembaga Penelitian dan Pengabdian kepada Masyarakat (LPPM UKI), Sekda Provinsi Maluku, Bapeda Provinsi Maluku, BPP Provinsi Maluku, dan kelompok masyarakat Maluku yang sudah bersedia melakukan berbagai diskusi. Kami ucapkan terima kasih juga kepada FEB UKI dan LPPM UKI.

\section{REFERENSI}

BNPP Badan Nasional Pengelola Perbatasan. (2011). Peraturan Kepala BNPP No 2 Tahun 2011 tentang Rencana Induk Pengelolaan Batas Wilayah Negara Dan Kawasan Perbatasan Tahun 20112014.

BNPP Badan Nasional Pengelola Perbatasan. (2015). Peraturan Badan Nasional Pengelola Perbatasan Nomor 1 Tahun 2015 tentang Rencana Induk Pengelolaan Perbatasan Negara Tahun 20152019.

Istijono, Bambang, (2012). Pengelolaan Batas Wilayah Negara dan Kawasan Perbatasan, Arah Kebijakan Menuju Kebijakan yang Terarah, Jurnal Puskasastra Pusat Kajian Strategis, Juli Desember 2012 hal 48-51, Jakarta.
Kennedy P.S.J, Tobing S.J.L, Toruan R.L., Tampubolon E., Heatubun A., Nomleni A. (2018). Kajian Normatif: Pengelolaan Perbatasan dan Kelembagaan Pusat-Daerah berdasarkan Rencana Induk Pengelolaan Perbatasan Negara, Ikraith Ekonomika Vol 1 No 2 Bulan November 2018.

Permendagri (2010). Peraturan Menteri Dalam Negeri No. 31 Tahun 2010 tentang Organisasi dan Tata Kerja Sekretariat Tetap BNPP.

Permendagri (2011). Peraturan Menteri Dalam Negeri No.02 tahun 2011 tentang Pedoman Pembentukan Badan Pengelola Perbatasan di Daerah

Perpres (2010). Peraturan Presiden No.

12 Tahun 2010 tentang Badan Badan Nasional Pengelola Perbatasan (BNPP).

Poetro, Aryawan Soetiarso, (2015), Kebijakan Pembangunan Kawasan Perbatasan 2015-2019, Buletin Tata Ruang \& Pertanahan, edisi 1 tahun 2015, Direktorat Tata Ruang dan Pertanahan Badan Peencanaan Pembangunan Nasional.

UU RI. (2004). Undang-Undang No.25/2004 tentang Sistem Perencanaan Pembangunan Nasional.

UU RI. (2008). Undang-Undang No.UU.43/ 2008 tentang Wilayah Negara. 